\title{
PARECERES.
}

\section{Plágio, cópia e contrafação penal...}

\author{
Washington de Barros Monteiro \\ Catedrático de Direito Civil na Faculdade de
} Direito da Universidade de São Paulo.

\section{Consulta.}

O consulente, autor do livro Direito Financeiro - Curso de Direito Tributário, publicado em São Paulo por José Bushatsky editor, em 1. ${ }^{a}$ edição, 1964, 2. ${ }^{a}$ edição 1969 e 3. ${ }^{a}$ edição 1971, anexa à presente um exemplar da 2. ${ }^{a}$ edição e juntamente o livro Vinte Lições de Direito Fiscal, volume 1, publicado com o nome de A. .P .A. ., com anotações à margem das cópias "ipsis litteris" da obra de que é autor às págs. $16,17,18,19,20,22,23,24,25,26,27$ (28 em branco), 30,31 (32 em branco), 33, 34, 67, 68, 69 (70 em branco), 71, 72, 73, 74, 75, 76, 77 (78 em branco) , 79, 81, 93, 98, 99, 100, 101, 102, 103, 104, 105, 106, 107 (108 em branco), $109,110,111,112,113,114,115,116,117,118$.

Além das cópias "ipsis litteris" e sem aspas, $\mathrm{V}$ Ex. ${ }^{\mathrm{a}}$ poderá ainda ver as anotações em várias outras páginas, de "plágios" da mesma obra do autor ora consulente, sendo certo que o texto do indigitado livro indo de pág. 7 a 118 e descontadas as páginas, inteira ou parcialmente em branco, os textos copiados ou plagiados do autor correspondem a mais de $50 \%$ desse livro! 
O consulente pede ainda a atenção de V. Ex. ${ }^{\mathrm{a}}$ especialmente para o cotejo entre as páginas 246 de seu livro e pág. 113 da cópia, pois o consulente como autor ilustrou essa passagem com solução de causa que patrocinou como advogado de cliente seu no ano de 1947, quando o copiador que se formou pela Faculdade Católica de Direito de Santos somente a 3/2/1958 e foi inscrito na OAB sob n. ${ }^{\circ} 11.992$, em 6/12/1960 (certidão anexa), não era sequer advogado, pois tinha 14 anos e no entanto, pelo texto apócrifo, ele usurpa também não só a autoria da defesa do tema em juízo mas ainda a posição de advogado que o ora consulente teve mediante procuração "ad judicia"

$\mathrm{V}$ Ex. ${ }^{\mathrm{a}}$ poderá ainda verificar que de tal forma foi feita cópia "ipsis litteris" que publicando em 1971, o servil copiador nem sequer atualizou o texto, copiando até os erros ou situações desatualizados.

- à pág. 112, copiou tão servilmente que transcreve a informação de que continua em nosso país o regime de participação das multas quando o art. $^{\circ} 196$ da Emenda Constitucional n. ${ }^{\circ} 1$ de 17 de outubro de 1969 já o aboliu. Isto es-

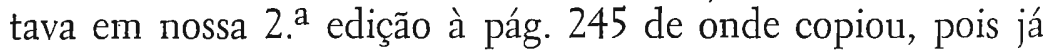
na 3. a edição de 1971 à pág. 246 excluimos esse trecho.

- na mesma página 112 copiou o mesmo erro tipográfico $\$ 15$ que era $\S 4 .^{\circ}$

- na mesma página deixou duas vezes art. ${ }^{\circ} 150$ da Constituição onde em 1971 já passou para art. ${ }^{\circ} 153$, o que prova a cópia servil.

A nosso ver, revelando má fé, o falso autor que copiou a obra do autor em quase todos os capítulos e tanto da $1 .^{\mathrm{a}}$ como da 2. edição, referiu apenas em dois capítulos que foi "consultada" a 2. a edição (vide págs. 107 e 117) onde só fez cópia sem aspas e sem autorização do autor que o desconhece e ainda retirou as aspas das citações de autores e che- 
gou ao cúmulo de suprimir as citações de rodapé dos autores citados no original!

Aliás, como a mais requintada prova de que esse indivícluo é um usurpador, veja $\mathrm{V}$ Ex. a apenas a título informativo, que chamando de "capítulo XVII o capítulo V" da Constituição colocou-o no falso livro como "seu" último capítulo (págs. $119 / 125$ ) , uma cópia do texto dos arts. 18 a 26 da Constituição Federal com as notas de rodapé começando por (34), dos Comentários do eminente Professor Catedrático Oscar Dias Corrêa, edição da Editora Alba, Rio de Janeiro, 1970, cujo exemplar exibimos a $\mathrm{V}$ Ex. ${ }^{\mathrm{a}}$

Também pela leitura $\mathrm{V}$ Ex. ${ }^{\mathrm{a}}$ poderá verificar que truncando e embaralhando trechos, numa demonstração de crassa ignorância, esse indivíduo acarreta não só danos pecuniários mas também morais à obra didática do autor ora consulente.

Cotejando os livros, pode $\mathrm{V}$ Ex. ${ }^{a}$ dar-nos seu parecer se no çaso se trata de "plágio", "cópia e/ou contrafação?"

Em caso positivo, pode $\mathrm{V}$ Ex. ${ }^{\mathrm{a}}$ esclarecer se cabe busca e apreensão, indenização e/ou ação penal?

\section{Parecer.}

1 Na consulta, que me dirigiu, o Professor Ruy BarBosa Nogueira apontou inúmeros tópicos de seu livro Direito Financeiro - Curso de Direito Tributário, editado por José Bushatsky, e, presentemente, em sua terceira edição, que teriam sido copiadas e plagiados por A. .P..... ., na obra que acaba de publicar, intitulada 20 lições de direito fiscal, Volume I, editada pelo Instituto Paulista de Administração de Empresas.

Para bem responder ao consulente, tive o cuidado de cotejar os vários trechos que o ilustre catedrático menciona. A cópia é realmente servil. Ipsis litteris, sem a menor cerimônia, 
o copista reproduziu frases, parágrafos, períodos e páginas inteiras daquele que tomara como modelo para a usurpação.

Além de copiar, o contrafator igualmente plagiou, apresentando, conscientemente, textos de outrem como se fossem de sua própria lavra ou invenção. A aproximação ou semelhança entre os textos confrontados é gritante.

Muito significativo é o episódio revelado pelo consulente, que ilustrou certa passagem com o desfecho de causa, em que interviera como advogado, no ano de 1947, sendo essa passagem, estritamente pessoal e exatamente nos mesmos termos, reproduzida pelo Sr. A.P.A., como se fora própria.

De modo idêntico, os anacronismos em que o copista incidiu, igualmente especificados na consulta, e que inadvertidamente cometeu por não se achar atualizado com a legislação, tendo copiado de edição anterior erros tipográficos dessa edição, que também copiou; o episódio referente ao Professor Oscar Dias Corrêa; tudo deixa claramente evidenciado que, de fato, houve usuparção, que é, sem dúvida, uma das mais clamorosas, com que me tenho defrontado na vida profissional.

2 Ora, a lei detesta a cópia e o plágio e condena, por isso, aquele que, deslealmente, se entrega à pilhagem de obras alheias, inculcando-as depois como próprias.

Essa proteção dos direitos autorais exerce-se como dignificação do trabalho literário, científico e artístico (Conf. Arquivo Judiciário, 108/218-109/87)

Manifesta-se ela tanto no que concerne aos interesses patrimoniais, como no que diz respeito aos interesses morais.

Sob o primeiro aspecto, a lei confere ao autor com exclusividade, o direito de reproduzir a propria obra, dela retirando todos os resultados econômicos, que seja apta a produzir.

E sob o segundo, outorga-lhe o direito de se opor a qual- 
quer reprodução fraudulenta, seja qual for a modalidade de que se revista (cópia, plágio, contrafação, esbulho)

Sem dúvida, existe o direito de citar obra alheia (Código Civil, n. I, do artigo 666) Citação não constitui contrafação. Antes valoriza a obra citada, contribuindo para sua maior difusão e acolhimento por parte do público, a que se destina.

Mas, para ser admitida, a citação deve apresentar papel secundário, no conjunto da obra. Não é êsse, entretanto, o caso do Sr. A.P.A., em cujo livro os trechos usurpados têm absoluta primazia.

Como afirma Piola-Caselli (Nuovo Digesto Italiano, voc. Diritto di Autore, n. 74), qualquer pessoa pode usar, nos próprios trabalhos, o conteúdo de obras alheias, bem como os respectivos elementos integrantes, como fatos, conceitos, sentimentos, tema, sistema, método, estilo, forma literária, maneira artística, vocabulário lingüístico. Não é lícito, porém, levar a utilização a ponto de usurpar o complexo de todos esses elementos, dos quais irradia a individualidade da representação intelectual alheia.

3. Persuadido, destarte, de que, na espécie em debate, simultaneamente concorrem plágio e cópia, aliás, insistentes, reiterados e repetidos, cumpre-me acrescentar que, contra o usurpador caberão as seguintes providências judiciais: a) medida preparatória de busca e apreensão dos exemplares expostos à venda nas livrarias; b) indenização por perdas e danos e ação penal.

A medida preparatória tem seu suporte legal no artigo 676, n. III, do Código de Processo Civil. No acórdão publicado na Revista dos Tribunais, 301/186, o Egrégio Tribunal de Justiça do Estado efetivamente admitiu busca e apreensão, uma vez que o usurpador imprimira e colocara à venda obra alheia contrafeita.

Relativamente à ação de indenização por perdas e danos, 
o suporte legal da pretensão é o artigo 669 do Código Civil. Como decidiu o mesmo Tribunal de Alçada, no acórdão inserto na Revista dos Tribunais, 243/399, "tratando-se de violação de direito autoral, o dano, sem necessidade de qualquer outra demonstração, assenta-se no próprio uso irregular de obra artística, cuja reprodução seja proibida"

Finalmente, sob o aspecto penal, existe o crime de violação de direito autoral, que o Código Penal, ainda em vigor, reprime no artigo 184 e em que só se procede mediante queixa (artigo 186)

E o meu parecer.

\section{Autos sob n. ${ }^{\circ} 166 / 71$. Busca e Apreensão.}

1 Insta o requerente da Medida Preventiva "sub studio", ou seja "Busca e Apreensão", com adarga no artigo 676, III, do Código Adjetivo, lhe seja passado preambulamente o competente mandado, como decorrência do exercício do prudente arbítrio, que tem o juiz, nos moldes cautelares disposto no artigo 675 daquele diploma.

$\mathrm{E}$, dessarte se bate pela captura judicial de livros didascálicos concernentes às disciplinas de Ciência das Finanças, sob a alegação de existência de plágio, contrafação e cópia ilegal, no volume de autoria do requerido, sob a denominação "Vinte Lições de Direito Fiscal", editado pelo Instituto Paulista de Administração de Empresas, a fim de que se arrebatem, de possíveis infratores, exemplares lançados à venda, já em comércio, de propriedade científico-didáticas, de que advém violação de Direito Autoral. - Por conseguinte, é, pois, medida assecuratória decorrente dos direitos do autor, mercê do que prescreve substantivamente o artigo 672.

1 1) Em verdade, o mandado concessivo da busca e apreensão, liminar, sem a audiência da parte contrária, medi- 
da essa puramente provisória, pressupõe antes de mais nada, direito patente por sobre a coisa a ser apreendida, ou então, pelo menos em potencial, e, de resto, é providência, que se submete à prudência da resolução do Juiz, que tem de apreciar o bem ou mau uso dessa atribuição arbitral, sob o sentido de que a prévia citação da parte adversa, de qualquer modo, possa ou não prejudicar a efetivação da medida.

2. Resulta, portanto, "in casu", que o conhecimento da postulação preventiva, poderia tornar ineficaz o pedido, cujo fundamento não se abala em embaraço diante da determinação de caráter restritivo, contido no artigo 683 do Código de Processo Civil posto que é providência de urgência, a qual na realidade, não comporta mesmo qualquer dilação, a não ser que se admita a sua manifesta inocuidade.

Evitar-se-á assim qualquer risco do desaparecimento dos noticiados exemplares, expostos às prateleiras de Livrarias; mas, sob outra área, assegura-se a JustiçA contra possíveis manobras lesivas, em que se busca a conservação do escopo e finalidade judicial.

Não se excede, conseguintemente, a medida ora em uso, a qualquer violência a direito dos requeridos.

3 Expeça-se, portanto, o mandado prefacial de Busca e Apreensão dos volumes sob o título "Vinte Lições de Direito Fiscal", por Ailton Pinto Alves, volume 1", editado pelo "Instituto Paulista de Administração de Empresas", o que deverá ser cumprido com urgência urgentíssima.

4 Como derivação consequencial, diligencie os Senhores Oficiais de Justiça, afetos ao cumprimento do mandado, $\epsilon$ apreensão dos mencionados exemplares que porventura se encontrem em Livrarias da Comarca da Capital de São Paulo, lavrando-se em tudo o necessário auto, com as cautelas de estilo. 
5 A seguir, proceda-se à citação na forma do $\S 10^{\circ}$ do artigo $5^{\circ}$ do C.P.C., de Ailton Pinto Alves e Instituto Paulista de Administração de Empresas, para, querendo, em 48 horas, oferecer contestação ${ }^{1}$

Int.

São Paulo, 19 de agosto de 1971.

\author{
Jacintho Elias Rocha Brito \\ Juiz de Direito da 22. ${ }^{\mathrm{a}}$ Vara Cível
}

1. Procedida a busca e apreensáo, o requerido náo contestou a medida e medante acordo pagou as indenizaçбes, sendo este homologado pelo MM. Juiz, ficando os autos arquivados no Cartórlo do $22 .^{\circ}$ Ofício Cível da Capital, conforme processo $166 / 71$. 